\title{
An Examination of the Factors Involved in Agricultural Reuse: Technologies, Regulatory and Social Aspects
}

\author{
Ezio Ranieri ${ }^{1}$, Harold Leverenz ${ }^{2}$, George Tchobanoglous ${ }^{2}$ \\ ${ }^{1}$ Engineering Faculty of Taranto, Polytechnic University of Bari, Bari, Italy \\ ${ }^{2}$ Department of Civil and Environmental Engineering, University of California, Davis, USA \\ E-mail: e.ranieri@poliba.it, \{hlleverenz,gtchobanoglous\}@ucdavis.edu \\ Received December 16, 2010; revised February 9, 2011; accepted March 19, 2011
}

\begin{abstract}
Factors that impacts agricultural reuse are examined in the paper. The objective of this work is to assess the factors involved in agriculture reuse by presenting a comparison of three wastewater treatment plants used for food crop irrigation: Adelaide, South Australia; Foggia, South Italy and Monterey, California. An analysis of the driving forces for reuse, regulatory requirements, and other factors affecting the water reuse systems are described. A comparison of treatment technologies and costs is also performed including pretreatments, biological steps, filtration, sedimentation and disinfection options. As a consequence of global warming that has increased the frequency and severity of natural disasters like the drought, the impacts of climate change and seasonality is discussed in the paper. A possible scenario of the future trend for agriculture reuse including the influence of the increase in urban water use, the increase in salinity and the acceptability of products is lastly considered.
\end{abstract}

Keywords: Climate Change, Groundwater, Regulatory Settings, Salinity, Treatment Processes

\section{Introduction}

The importance of wastewater reuse is increasing as a result of growing water demands in semi-arid areas all over the world. Wastewater reuse in agriculture is a cost-benefit operation from both an economic and environmental point of view; the implementation of which is a balance of opportunity and necessity [1,2].

In the past two decades, there has been a notable increase in the use of treated wastewater for crop irrigation, especially in arid and seasonally arid areas of both industrialized and developing countries. Recent effect of world climate change imposes a new attention towards water savings and the development of new and affordable technologies for wastewater reuse.

The impact of drought can be greatly exacerbated by the inefficient use of water, inadequacies in infrastructure, water use, demand management and in legislative frameworks and regulatory mechanisms. The economic impact of droughts has been approximately 25 billion $€$ over the last 30 years and was nearly 12 billion $€$ in 2003 [3]. This study has shown that the worst drought in the USA was more than twice the cost of the worst flood.

Wastewater reuse has developed from a basic method of disposing of wastewater without any treatment to an often highly engineered technique of wastewater upgrading and water resources augmentation in waterscarce regions throughout the world. Due to limited water resources, typically water-stressed countries in dry climates like South Australia, South Italy and the State of California, have developed wastewater reuse strategies and programme acknowledging the beneficial role wastewater reuse can play in integrated water management, $[1,4,5]$.

In California, where the largest number of water reuse facilities existing in the United States is found, there is around 434 million $\mathrm{m}^{3}$ of municipal wastewater currently reused with, in 1999, water reuse for agricultural irrigation amounting to $68 \%$ of the total recycled water used [1].

While most of waste reuse systems have a number of driving forces in common, the individual circumstances and specifications for each system is subject to site specific circumstances. Given the similarity in the case studies, it is of interest to investigate the factors that contribute to the water reuse scheme developed for each situation.

The objective of the paper is to examine the factors 
involved in agriculture reuse by presenting a comparison of three systems used for food crop irrigation in Monterey California (USA), Adelaide (Australia), and Apulia (Italy). An analysis of the driving forces for reuse, regulatory requirements, treatment processes employed, and other factors affecting the water reuse systems is presented.

\section{Background}

\subsection{Water Reuse in Agriculture}

The interest and the increase in water reuse for crop irrigation has occurred as a result of other several factors:

- Increasing scarcity of alternative waters for irrigation, exacerbated by increasing urban demand for potable water supplies;

- Increasing salinity of groundwater in coastal areas where excessive groundwater withdrawals are facilitating sea water intrusion into fresh water aquifers;

- $\quad$ Growing recognition by water resource planners of the importance and value of wastewater reuse;

- Increasing cost of fresh water and the need for reliable, drought proof water supplies;

- High cost of artificial fertilizers and the recognition of the value of nutrients in wastewater, which significantly increase crop yield;

- Millenium Development Goals (MDGs) especially the goals for ensuring environmental sustainability $[6,7]$;

- Increasing regulations related to effluent quality discharged to the environment.

While secondary effluent quality is adequate for direct agriculture reuse on certain crops, the addition of advanced tertiary treatment (e.g., filtration and disinfection steps) typically results in water that is suitable for most unrestricted irrigation purposes [8].

Regardless of the agricultural water quality issues, important criteria that drive water reuse for irrigation purposes are:

- $\quad$ Large nearby important agricultural region;

- $\quad$ Concerns about degradation of marine environments from untreated wastewaters;

- Sea water intrusion from excessive pumping of groundwater for agriculture;

- Low precipitation.

\subsection{Factors That Impacts Agricultural Reuse}

The use of reclaimed water for irrigation is subject to factors such as the availability and cost of alternative water sources, the variability in irrigation demand due to seasonal uses, and the suitability of the water quality for the crops under consideration. As a consequence of the recent observed climatologic data in all area of the world and particularly in the semi-arid regions [9] and as a consequence of the lower water availability for agriculture lower income from agricultural sector we can affirm that climate change has a considerable impact on wastewater reuse . Other impact to be considered are seasonality, acceptability of the product, increase in urban and ecological water use, increase in salinity, operational and capital costs.

\subsection{Regulatory Issues}

The regulatory requirements for the use of reclaimed water for unrestricted irrigation is based on the need to protect public health in the event of a cross connection with a potable water system or contact with water during irrigation events. Irrigation of food crops generally requires a high level of water quality to ensure that the agricultural workers and consumers of the agricultural products are protected from disease causing microorganisms [10].

There a large number of potential legal and regulatory instruments which are available for pollution prevention and control, and examples of which can be found in operation in many industrialized countries. Developing countries need to examine these in the context of their capability to deliver the end result without over-stretching their resources.

Risk avoidance or risk minimization certainly should be principal elements in the determination of wastewater reuse and recharge water standards and guidelines in relation to their end uses. However, technological and economic factors also enter into the ultimate quality parameters. Aesthetic factors of taste, odor, and appearance must be important considerations for water even if they do not directly relate to the safety of the water, because consumer acceptance and confidence in the quality and safety are essential [2].

\section{Case Study 1 Monterey, California}

\subsection{The Physical Setting}

The area around Castroville near Monterey, CA, is a national center for production of various food crops, generating almost \$3 billion/yr as of year 2004. Until the 1980s, groundwater was the primary source of irrigation water in Monterey County. Intensive groundwater withdrawal resulted in depletion of groundwater level and seawater intrusion, rendering some well water unsuitable for irrigation. Meanwhile, expansion of wastewater treatment facilities was required because the existing wastewater treatment facilities in the region were reach- 
ing full capacity. Following the decision to pursue irrigation of these food crops with reclaimed water, a 10-year study was conducted to assess the safety and feasibility of agricultural irrigation with reclaimed water [11].

\subsection{The Regulatory Setting}

The California Department of Health services (DHS) has established the wastewater reclamation criteria (State of California, 1978) known as title 22. The current Water Recycling Criteria were adopted by DHS in 2000 [12]. This water recycling criteria include water quality standards.

\subsection{Treatment Processes}

The wastewater reclamation plant was established in the early 1920s and subsequently modified and upgraded to include Title 22 process: coagulation, flocculation, sedimentation, filtration and chlorination. The process is shown on Figure 1.

\section{Case Study 2 Adelaide, Australia}

\subsection{The Physical Setting}

In this dry agricultural coastal region (rainfall $600 \mathrm{~mm} / \mathrm{yr}$, evaporation $2000 \mathrm{~mm} / \mathrm{yr}$ ), water availability is a limiting factor to crop production, and groundwater resources have been overdrawn for irrigation needs [13]. Consistent with a South Australia policy issued in 1993 to encourage sustainable water reuse, and the 1995 Environmental Protection Act, further promoting and regulating water reuse, the City of Adelaide began considering reclamation and reuse of the Bolivar WWTP effluent to satisfy some seasonal irrigation demands, and reduce adverse ecological effects caused by nutrients discharged in the marine environment. Adelaide is perhaps the only industrialized city in the world to have constant problems of water shortage, because its water supply depends up to $90 \%$ on Murray river. Beside aiming at providing reclaimed water for agricultural use during peak demand in the summer time, and minimizing year-round nutrient loads to Gulf St Vincent, water reuse project also presented an opportunity for generating economic benefits in the region, using taxpayer funds to both improve coastal water quality and promote agricultural production, rather than simply building a non-revenue generating nutrient removal upgrade to the Bolivar plant. To maximize the economic goals, planners determined that reclaimed water should be stored during low demand season, thus increasing availability for summertime peak irrigation season. A multi-year research project was implemented to ensure that the treatment technology selected for production of the reclaimed water could be used to recharge the aquifer sustainably.

\subsection{The Regulatory Setting}

The regulatory requirements are similar to the standards set in California for food crop irrigation and are also based on suitability to conduct ASR during the winter storage period.

\subsection{Treatment Processes}

The Bolivar Wastewater treatment plant treats $40 \times 10^{6} \mathrm{~m}^{3} / \mathrm{yr}$ and consists of primary sedimentation, secondary treatment using biological trickling filters and stabilization ponds prior the discharge in Gulf of St. Vincent, South Australia. In a second moment others treatments were added with the goal of recycling the treated water: dissolved air flotation with filtration (DAFF) disinfection contact tank, balancing storage reservoir, as shown in Figure 2.

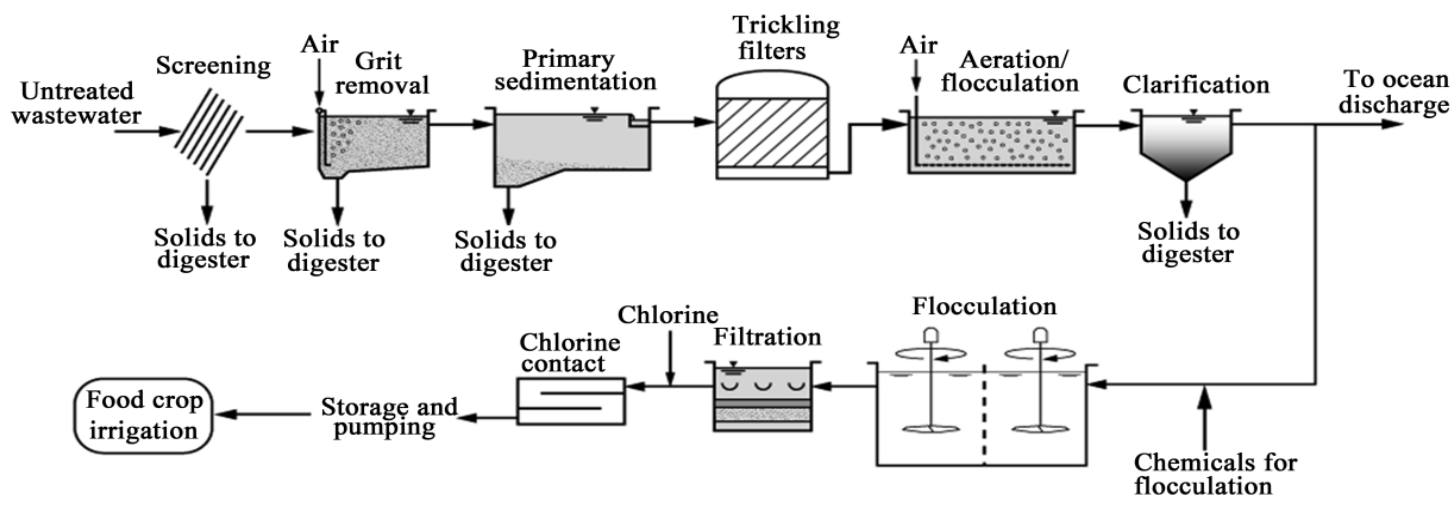

Figure 1. Process flow diagram for Monterey regional water pollution control facility for production of water for unrestricted irrigation reuse. 


\section{Case Study 3 Apulia, Italy}

\subsection{The Physical Setting}

The Apulian Region, characterized by average rainfalls of less than $600 \mathrm{~mm}$ is historically a water-deficient area with supplies heavily depending on importations from neighboring areas to meet domestic, agricultural, and industrial needs [14]. The impact of wastewater on the quality of deep ground water resources for drinking water and the quality of seawater for recreational purposes (i.e., tourism) is a major consideration. The total Apulian area is approx. 1900000 hectars; the agriculture area represents 66\%, approx. 1250000 hectars. In recent years the irrigated agricultural area has grown so that now it represents approx. $30 \%$ ot the total agricultural area. In particular flower and vineyard have been expanded while cereal and olive colture have decreased. In Apulia operate six "Agricultural Consortium” Gargano, Capitanata; Terre d'Apulia, Stornara e Tara; Arneo e Ugento Li Foggi that manage a total irrigated area of approx. 360000 hectars. Private area is largely predominant area for irrigation representing 285000 hectars.

\subsection{The Regulatory Setting}

Existing Italian legislation (Decree 185/03, Table 2) sets the limits very low and depending mainly on chemical parameters and not on microbial parameters.

Moreover, the law prescribes that in the presence of unconfined aquifers in direct contact with surface waters, adequate preventive measures must be used to avoid any deterioration of their quality.

\subsection{Treatment Processes}

Wastewater treatment for agriculture reuse is performed by two plants in series. The first one a conventional me- chanical biological treatment plant, the next one is a physic-chemical plant treating approx. $12 \times 10^{6} \mathrm{~m}^{3} / \mathrm{yr}$. The process flow diagram is shown on Figure 3.

Because of secondary wastewater may contain some synthetic organic chemicals even at low concentrations ozone pre-oxidation process has been used to destroy trace constituents, including pesticides and herbicides. The choice of inserting a pre oxidation is explained also with: 1) the need to ensure a pre-disinfection step to avoid biofilm in the subsequent steps; 2) to facilitate the GAC adsorption in the subsequent phase. Clarification should be optional. If TSS concentration is lower than $80 \mathrm{mg} / \mathrm{l}$ no chemicals were added. This implies a lower sludge formation.

\section{Discussion}

The three selected agricultural reuse case studies Monterey, California, Adelaide, Australia, and Foggia, Italy were analyzed because of their similar conditions related to climate and water scarcity. Their average annual temperature is compared on Figure 4.

Background information for each of the case studies is described in Table 1.

\subsection{Comparison of Regulations}

Water quality criteria for irrigation with recycled municipal wastewater applicable for each of the case studies are given in Table 2.

As shown in Table 2 the constituents for whom the respect of the limits are mandatory are for Italy in number much higher than in other two countries. Based on the data presented above, it is clear that the requirements set for the Italian case study for food crop irrigation with reclaimed water are more stringent than the standards established in other countries, such as the California and

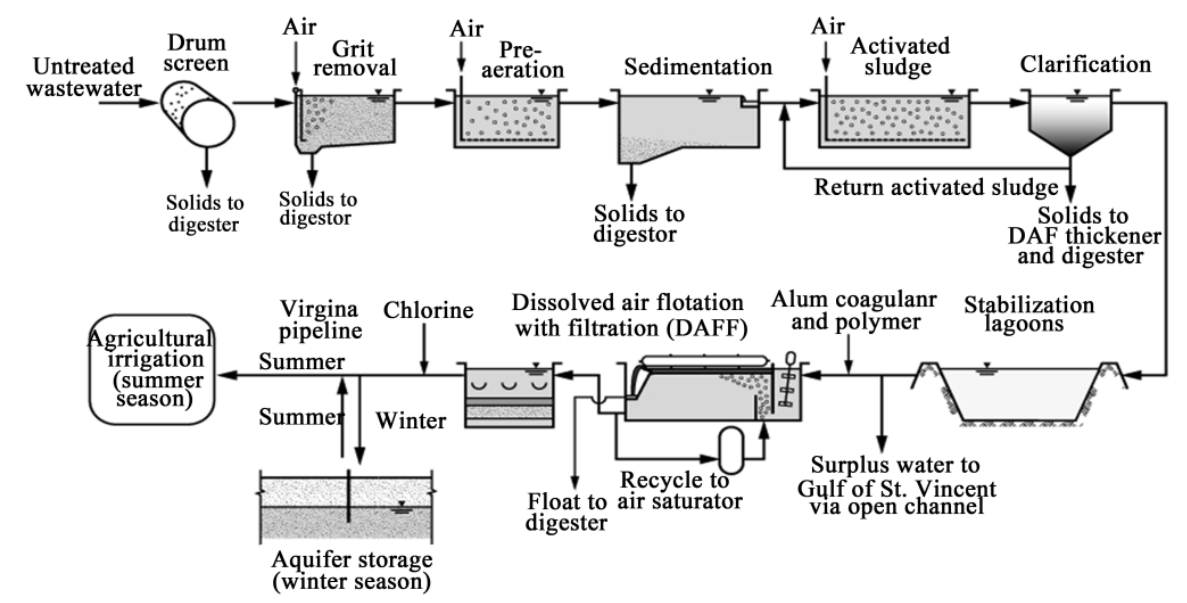

Figure 2. Process flow diagram for Bolivar sewage treatment facility for production of water for unrestricted irrigation reuse. 


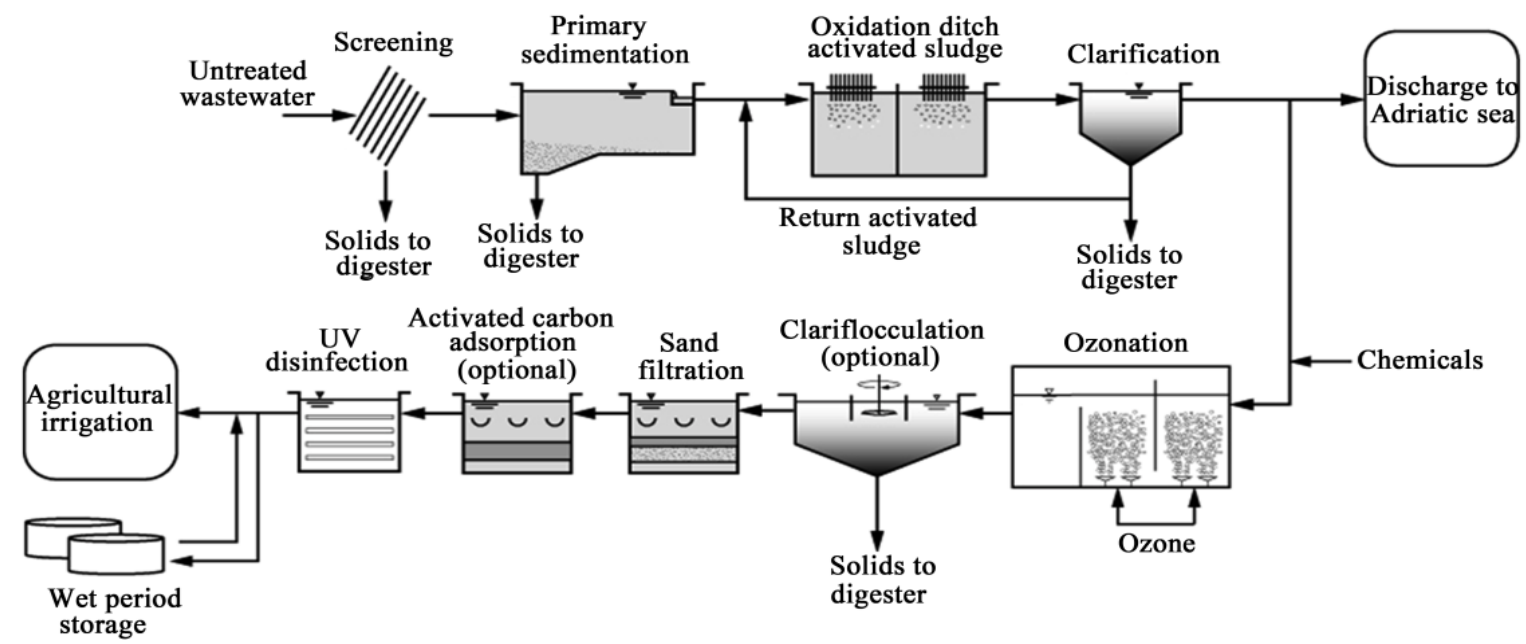

Figure 3. Process flow diagram for the Foggia wastewater reclamation facility for production of water for unrestricted irrigation reuse.

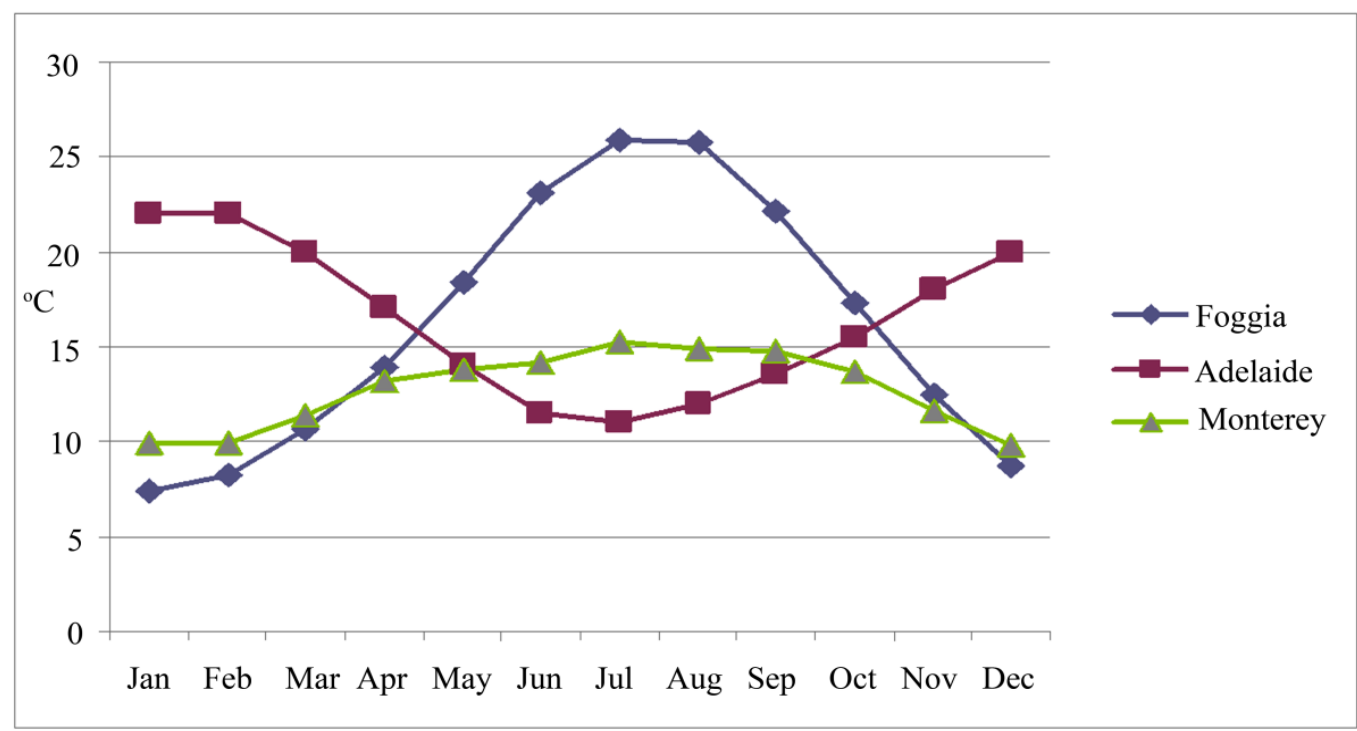

Figure 4. Average temperature in Foggia, Adelaide, Monterey during the year.

Table 1. Summary of irrigated area and water use.

\begin{tabular}{|c|c|c|c|c|c|}
\hline Region & $\begin{array}{l}\text { Volume of recycled water } \\
\text { used for irrigation, } \mathrm{m}^{3} / \mathrm{yr}\end{array}$ & $\begin{array}{l}\text { Percent of flow } \\
\text { treated used for } \\
\text { irrigation }\end{array}$ & $\begin{array}{l}\text { Irrigated area } \\
\text { with recycled } \\
\text { water, ha }\end{array}$ & $\begin{array}{c}\text { Management of } \\
\text { non-irrigation water }\end{array}$ & $\begin{array}{l}\text { Typical Irrigated } \\
\text { crops }\end{array}$ \\
\hline Monterey & 25000000 & 85 & 4700 & $\begin{array}{l}\text { Discharge to Pacific } \\
\text { Ocean }\end{array}$ & $\begin{array}{l}\text { artichokes, } \\
\text { brassicas, } \\
\text { strawberries, } \\
\text { salad crops }\end{array}$ \\
\hline Adelaide & 280000000 & 100 & 20000 & $\begin{array}{l}\text { Discharge to sea } \\
\text { and/or aquifer sto- } \\
\text { rage and recovery }\end{array}$ & $\begin{array}{l}\text { vineyards, } \\
\text { olive trees, } \\
\text { salad crops, } \\
\text { brassicas }\end{array}$ \\
\hline Apulia & 12000000 & 20 & 4000 & $\begin{array}{l}\text { Discharge to canals } \\
\text { leading to Adriatic } \\
\text { Sea }\end{array}$ & $\begin{array}{c}\text { vineyards, } \\
\text { olive \& peach trees, } \\
\text { artichokes }\end{array}$ \\
\hline
\end{tabular}

Australia. In California more importance is given to the- microbiology of the water and it should be noted that 
also Italy regulation should be performed in that way, because of E.coli is the unique microbiological parameter and should not perform the total microbiological quality of water.

The surface water supplies currently used for the water supply of Southern Italy would not be able to meet the standards established for the reclaimed water. Thus, the standard may be considered overly restrictive for the water reuse application in question.

In California and Australia, standards for many constituents are provided as a guideline, not as a set limit and, therefore, not limiting the implementation of water reuse projects unnecessarily. Several factors or perceptions that may have contributed to the development of these standards include:

Table 2. Selected water quality for food crop irrigation.

\begin{tabular}{|c|c|c|c|c|}
\hline Parameter & Unit & California & Apulia, Italy & Southern Australia \\
\hline $\mathrm{pH}$ & & & $6-9.5$ & $4.5-9.0$ \\
\hline SAR & & & 10 & $2-102^{\mathrm{a}}$ \\
\hline TSS & $\mathrm{mg} / \mathrm{L}$ & NS & 10 & \\
\hline Turbidity & NTU & $<2$ & & $<2$ \\
\hline BOD5 & $\mathrm{mg} / \mathrm{L}$ & NS & 20 & \\
\hline COD & $\mathrm{mg} / \mathrm{L}$ & & 100 & \\
\hline Phosphorus, total & $\mathrm{mg} / \mathrm{L}$ & & 2 & \\
\hline Nitrogen, total & $\mathrm{mg} / \mathrm{L}$ & & 15 & \\
\hline Nitrogen, ammonium & $\mathrm{mg} / \mathrm{L}$ & & 2 & \\
\hline Conductivity & $\mathrm{mg} / \mathrm{L}$ & & 3000 & \\
\hline Metals & $\mathrm{mg} / \mathrm{L}$ & & & \\
\hline Aluminum & $\mathrm{mg} / \mathrm{L}$ & & 1 & 5 \\
\hline Arsenic & $\mathrm{mg} / \mathrm{L}$ & 0.1 & 0.02 & 0.1 \\
\hline Cadmium & $\mathrm{mg} / \mathrm{L}$ & 0.01 & 0.005 & 0.01 \\
\hline Chromium & $\mathrm{mg} / \mathrm{L}$ & 0.1 & 0.1 & 1 \\
\hline Iron & $\mathrm{mg} / \mathrm{L}$ & & 2 & 1 \\
\hline Lead & $\mathrm{mg} / \mathrm{L}$ & 5 & 0.1 & 0.2 \\
\hline Mercury & $\mathrm{mg} / \mathrm{L}$ & 0.01 & 0.001 & 0.002 \\
\hline Selenium & $\mathrm{mg} / \mathrm{L}$ & 0.02 & 0.01 & 0.02 \\
\hline Zinc & $\mathrm{mg} / \mathrm{L}$ & 2 & 0.5 & 2 \\
\hline Mineral oils & $\mathrm{mg} / \mathrm{L}$ & & 0.5 & \\
\hline Total phenols & $\mathrm{mg} / \mathrm{L}$ & & 0.1 & \\
\hline Total surfactants & $\mathrm{mg} / \mathrm{L}$ & & 0.5 & \\
\hline THMs (sum) & $\mathrm{mg} / \mathrm{L}$ & & 0.03 & \\
\hline Total chlorinated solvents & $\mathrm{mg} / \mathrm{L}$ & & 0.04 & \\
\hline Benzo (a) pyrene & $\mathrm{mg} / \mathrm{L}$ & & 0.00001 & \\
\hline Total pesticides & $\mathrm{mg} / \mathrm{L}$ & & 0.5 & \\
\hline Aromatic Nitrogen Solvents & $\mathrm{mg} / \mathrm{L}$ & & 0.01 & \\
\hline Benzene & $\mathrm{mg} / \mathrm{L}$ & & 0.001 & \\
\hline Pentachlorophenol & $\mathrm{mg} / \mathrm{L}$ & & 0.003 & \\
\hline \multirow[t]{2}{*}{ Total coliform } & No./100 mL & 2.2 (7 d med) & & \\
\hline & & 23 (30 d max) & & \\
\hline Fecal coliform (or E. coli) & No./100 mL & & & $<10$ \\
\hline \multirow[t]{2}{*}{ E. coli } & No./100 mL & & $10(80 \%)$ & \\
\hline & & & 100 (max) & \\
\hline Specific pathogens & & & & May be required \\
\hline
\end{tabular}

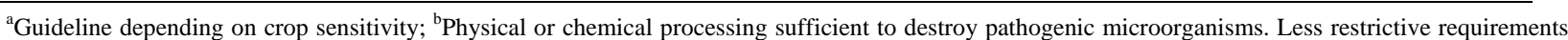
may apply where there is no direct contact between reclaimed water and the edible portion of the crop; ${ }^{\mathrm{c}}$ Food crops eaten raw where there is direct contact between reclaimed water and the edible portion of the crop. 
- $\quad$ Trace constituents in the wastewater from Apulia that would create a health hazard if the water was used for irrigation directly. As stated previously, in other countries, the primary health hazard that is addressed is pathogenic microorganisms, thus the requirement for filtration and disinfection. Where the primary risk is due to short term exposure, microbial pathogens are more relevant constituents. It should also be noted that in California and Australia, microbial risk is managed, in part, through specification of the treatment process and reasonable limits for indicator organisms.

- Other countries developed their water quality standards for reclaimed water irrigation in the 1970s, prior to awareness of trace chemicals that are now well documented in water. Similarly, the analytical capabilities to measure these constituents have made it more feasible to screen for these chemicals in water. However, there does not seem to be sufficient evidence to support the belief that the presence of these chemicals in water will create a health hazard due to deposition on the crop or through bioaccumulation. Thus, the basis for the standards should be reviewed to confirm that it is consistent with modern scientific understanding.

\subsection{Comparison of Treatment Technologies and Costs}

Treatment technologies and then the design of the water reuse treatment plant depend on the specific regulatory, so the design and the operational cost are quite different.

As evidenced in Table 3 though in Apulia standards are so restrictive no specific treatment is required neither suggested. The selection of a treatment process depends on site constrains, local expertise, and reliability in meet- ing regulatory goals. In general, the treatment process used most commonly for production of reclaimed water for unrestricted irrigation consist of a conventional activated sludge process followed by coagulation, flocculation, filtration, and disinfection.

In Table 4 are reported the operational costs based on the average flow in terms of cent US \$ per cubic meters of treated water as reported in the wwtp monthly factsheets.

The cost for Foggia wastewater treatment plant, although not high in absolute, are the highest in evaluation comparison, due to the more technologies applied. Therefore if there is no documented need as a consequence of chemical micropollutant in reclamation plant influent those technologies should be avoided, bypassing them, for containing costs.

Due to the difficulty of reaching so low standards a full physical-chemical is necessary in Italian case. Pre-ozonation has the function of breaking the organic complexes molecules and to transform them in a more absorbable composts. In the following GAC treatment the very low concentrations of chemicals are ensured. It is important to note that the existing treatment facilities of most large cities are located inappropriately with respect to water reuse, the use of all types of satellite and decentralized systems will become critical in the future [15], especially where no complex treatments were required.

\subsection{Impacts of Seasonality}

Seasonality is important either for the different water crops demand either for the different water characteristics entering in reclamation plant.

In both Monterey and Adelaide, there was a relatively urgent need to provide supplemental irrigation water to

Table 3. Summary of treatment requirements for unrestricted irrigation with reclaimed water.

\begin{tabular}{lc}
\hline Region & Treatment required \\
\hline California & Oxidation, coagulation, filtration, disinfection \\
Southern Australia & Oxidation, coagulation, filtration, disinfection \\
Southern Italy & Not specified \\
\hline
\end{tabular}

Table 4. Operational costs for three analyzed plants in US cent $\$ / \mathrm{m}^{3}$.

\begin{tabular}{|c|c|c|c|}
\hline \multirow{2}{*}{ Operational cost } & \multicolumn{3}{|c|}{ Approximate unit cost, cent $\$ / \mathrm{m}^{3}$} \\
\hline & Monterey & Adelaide & Foggia \\
\hline Electricity & 1.8 & 1.7 & 3.7 \\
\hline Chemicals & 3.0 & 2.9 & 0.4 \\
\hline Maintenance-replace & 2.3 & 2.2 & 4.5 \\
\hline Labour & 1.2 & 1.1 & 1.3 \\
\hline Total & 8.3 & 7.9 & 9.9 \\
\hline
\end{tabular}


support the existing agricultural industry. The quality of the water that was available for irrigation had been compromised due to long term over extraction followed by sea water intrusion. Interestingly, Apulia is also subject to periodic drought conditions that are anticipated to worsen in the future. During drought events, farmers in the Apulia region rely on groundwater to make up the required irrigation water, but the amount of available groundwater is limited and the quality is marginal. While there are plans to import additional water from the surrounding countries, this approach is subject to many conditions. The implementation of a water reuse scheme seems to be suitable for supplying some of the irrigation water demand in Southern Italy, yet in this region only two treatment facilities have the capacity to produce reclaimed water that can meet the applicable water quality standards. Thus, the regulatory requirements are inhibiting the use of reclaimed water for food crop irrigation.

\subsection{Acceptability of Product}

A pilot study [16] revealed that the public presents a strong hesitation towards any wastewater reuse application schemes related to food production, partially due to lack of adequate information as well as trust towards ruling and monitoring bodies. Their greatest fears are related to inappropriate food production and dangerous consumption, and as a result when reuse suggested applications became increasingly related to food they were presenting an increasingly negative approach. This, in correlation to their fear of a chemical toxic substance in the wastewater (primary reason of hesitation according to their responses), which can not be removed with existing technology ( $71 \%$ believe that) and by authorities (private or public) that can not be trusted (more than $60 \%$ of those answered feel this way) explain their hesitations.

Concern that irrigation with reclaimed water would harm the image of crops produced in Italy and, therefore, impact the marketability of Italian agricultural products. In both Monterey and Adelaide, these concerns also existed initially, but later proved not to be an issue. Thus, the lack of experience with water reuse programs could be a major factor contributing to the highly restrictive water quality standards.

\section{The Future for Agricultural Reuse}

\subsection{Increase in Urban and Ecological Water Use}

Freshwater demand is more and more increasing not only in more industrialized country but also in areas characterized by water scarcity. The economic and social development caused an increase in the demand of freshwater for domestic, industrial and agricultural sectors. Water resources management clearly impacts on many other policy areas (e.g., energy projections, land use, food security and nature conservation). Adequate tools are not available to facilitate the appraisal of adaptation and mitigation options across multiple water-dependent sectors, including the adoption of water-efficient technologies and practices. In the absence of reliable projections of future changes in hydrological variables, adaptation processes and methods which can be usefully implemented in the absence of accurate projections, such as improved water-use efficiency and water-demand management, offer no-regrets options to cope with climate change [17].

It should be added that water stress is also increasing due to population density, diffused pollution and short-term seasonal population increases due to tourism and increased demand for irrigation to improve agricultural productivity. At the same time, the EU Water Frame Directive requests an analysis of water use, which in some regions or basins could lead to a reduction of $15-20 \%$ of abstraction licenses, in order to protect surface and groundwater quality and quantity [18].

\subsection{Increase in Salinity}

Many areas of South West of Australia, California and Apulia are seriously affected by the increase of salinity problem due to the excessive use of groundwater and to the higher level of the sea-water interface.

For example, salinity levels in the headwaters of the Murray-Darling Basin in Australia are expected to increase by $13 \%$ - 19\% by 2050 [19]. In general, decreased groundwater recharge, which reduces mobilization of underground salt, may balance the effect of decreased dilution of salts in rivers and estuaries. Recent analyses of climate change over California have provided projections of the range of warming and other changes that the region may face by the end of the 21st century. The projected reduction in surface water availability and potentially increased water requirements is expected to cause California's farmers to respond by supplementing available irrigation waters by increasing groundwater pumping. However, increased pumping will increase energy costs, and diminishing quality of groundwater applied as irrigation water will generally increase soil salinity [20].

The Apulian (Southern Italy) karstic coastal aquifers consist of three types of aquifer zones: 1 ) areas with low vulnerability to seawater intrusion, 2) areas with high vulnerability and 3 ) areas with variable vulnerability in which the salt degradation largely depends on the ability to manage the well discharge. The water quality degradation caused by seawater intrusion appears to be a combined effect of an anomalous succession of drought pe- 
riods observed from about 1980 onwards and increased groundwater pumping, particularly during drought periods [21].

An important issue should regard the salinity: due to the high level of salinity content in the influent, limit should not be mandatory about this and it should based on the characteristic of the crops and of the source water [22].

Moreover artificial recharge of groundwater basins with treated wastewater should be recommended when the water is not used for agricultural purposes particularly where conjunctive use of surface water and groundwater resources is considered in the context of integrated water resources management $[1,23]$.

\subsection{Impacts of Climate Change}

Agriculture is not only a fundamental human activity at risk from climate change. About 1.4 billion ha of arable land (10 percent of total ice-free land) are used for crop cultivation and an additional 2.5 billion ha are used for pasture. In addition to land resources, agriculture is a major user of water. Over 200 million ha of arable land is under irrigation, utilizing 2500 billion $\mathrm{m}^{3}$ of water annually, representing $75 \%$ of fresh water resources withdrawn from aquifers, lakes and rivers by human activity [24].

It is projected that climate change will have a range of impacts on water resources and then in cropwater demand. In general, while moderate warming in highlatitude regions would benefit crop and pasture yields, even slight warming in low-latitude areas, or areas that are seasonally dry, would have a detrimental effect on yields. Regions where agriculture is currently a marginal enterprise, largely due to a combination of poor soils, water scarcity and rural poverty, may suffer increasingly as a result of climate change impacts on water [25].

Global warming has increased the frequency and severity of natural disasters like the drought. $0.75^{\circ} \mathrm{C}$ is the increase of the temperature over the past 15 years and this result in a lot more of evaporation.

Warm air holds more moisture, carrying it away from dry areas and towards wetter ones. Thus as global temperature rise, dry areas will likely get drier and wet areas wetter. Seasonal extremes will likewise intensify, as moisture accumulated in the dry season is shed in downpours in cooler times, leading to seasonal floods in regions otherwise prone to drought.

Atmospheric warming is also predicted to affect rainfall by altering global air circulation. At present, warm air carried from the topics by circulation loops called Hadley cells meets cool polar air carried by Ferrel cells in zones around $30^{\circ}$ north and south, creating arid zones.
As the planet warms, these zones are expected to expand and shift towards the Poles [9].

So while annual runoff increases are projected in Atlantic- and northern Europe [26], and decreases in central, Mediterranean and Eastern Europe [27-30].

This event brought farmers to an unsustainable situation. So water consumption crops as rice and cotton have been removed and substituted with grapes and fruits that needs less water; but farmers are seriously worry on what to do for living in the next future.

There is a consensus [30] that Mediterranean Basin (South Italy), South Western USA, Southern Australia will become more arid. This poses a particular risk for regions that already subsist on minimal rainfall or that depend on rain-fed agriculture. Meanwhile an hotter climate contains more moisture, this will not necessarily translate into more rain but it is likely to translate into changes in where the rain falls; and when the rain does come, it will likely arrive in more intense bursts, increasing the risk of flooding even in areas that are drying out. In fact IPCC notes that heavy precipitation events are projected to become more frequent and that an increase in such events is probably already contributing to disaster.

\section{Conclusions}

In the drought-stricken regions such as Southern Italy, Australia, and Southern California, where the additional resources brought by wastewater reuse can bring significant advantages to agriculture (e.g. crop irrigation) and tourism (e.g. golf course irrigation).

A comparison between three wastewater reclamation plant has been carried out. Differences in the complexity of the technological treatments are due to different regulations, so a standardization of the regulation is recommended around the world where standards should be addressed more to microbial community and pathogenic than to chemical constituents.

The most technological treatment plant (Foggia) results in a $30 \%$ higher operational costs as average. Therefore these treatments should be justified only with a heavy industrial contaminated wastewater influent.

The impact of climate change on water resources strongly suggests the improvement of wastewater reuse all the world.

It is also suggested the improvement of the artificial groundwater recharge because this is becoming increasingly important in groundwater management and particularly where the conjunctive use of surface water and groundwater resources is planned.

About salinity, this limit should be based on the characteristic of the crops and of the source water and 
should not be mandatory about this.

However wastewater reuse should be encouraged by government financial aid so that costs of wastewater should be comparable with that of fresh water supply and that should be adopted not only when is a need in period of for water shortage all the year round and year by year.

\section{Acknowledgements}

The authors would like to thank all the personnel of Department of Environmental Engineering and Sustainable Development of Technical Unversity of Bari and, in particular Prof. Edward Schroeder, University of California at Davis for his help and assistance. Special thanks to the Dean of Faculty of Engineering of Taranto.

\section{References}

[1] G. Tchobanoglous, et al., "Water Reuse: Issues, Technologies, and Applications,” McGraw-Hill, Boston, 2007.

[2] T. Asano and J. A. Cotruvo, "Groundwater Recharge with Reclaimed Municipal Wastewater: Health and Regulatory Considerations,” Water Research, Vol. 38, No. 8, 2004, pp. 1941-1951. doi:10.1016/j.watres.2004.01.023

[3] A. Markandya and J. Mysiak, "Options Méditerranéennes,” 2nd International Conference on Drought Management on: Economics of Drought and Drought Preparedness in a Climate Change Context, Istanbul, 4-6 March 2010, pp. 131-138.

[4] P. Dillon, "Water Reuse in Australia: Current Status, Projections and Research," Proceedings of Water Recycling Australia 2000 Conference, Adelaide, 19-20 October 2000, pp. 99-104.

[5] G. D’Arcangelo and E. Ranieri, "Municipal Wastewater Effluent Reuse in Apulia, South Italy," Proceedings of the 6th IWA Specialist Conference on Wastewater Reclamation and Reuse for Sustainability, Antwerp, 9-12 October 2007.

[6] WHO, "Guidelines for the Safe Use of Wastewater and Excreta in Agriculture and Aquaculture,” 1989.

[7] WHO, "Guidelines for the Safe Use of Wastewater, Excreta and Greywater in Agriculture,” 2006.

[8] U.S. Environmental Protection Agency, "Guidelines for Water Reuse,” US EPA/ 625r04108, September 2004.

[9] National Oceanic and Atmospheric Admnistration, "Monthly Report,” 2009. http://nosa.noaa.gov

[10] I. Hespanhol and R. Helmer, "Water Pollution Control: A Guide of Water Quality Management Principles,” United Nations Environment Program, Suffolk, 1997.

[11] B. Sheikh, R. P. Cort, W. R. Kirkpatrick, R. S. Jaques and T. Asano, "Monterey Wastewater Reclamation Study for Agriculture," Research Journal of the Water Pollution Control Federation, Vol. 62, No. 3, 1990, pp. 216-226.

[12] T. Asano, "Wastewater Reuse for Non-Potable Applications: An Introduction,” Proceedings of the International
Symposium on Efficient Water Use in Urban Areas: Innovative Ways of Finding Water for Cities, Osaka, 8-10 June 1999.

[13] B. Kracman, R. Martin and P. Sztajnbok, "The Virginia Pipeline: Australia's Largest Water Recycling Project,” Water Science \& Technology, Vol. 43, No. 10, 2001, pp. 35-42.

[14] L. Bonomo, C. Nurizzo and E. Rolle, "Advanced Wastewater Treatment and Reuse: Related Problems and Perspectives in Italy," Water Science and Technology, Vol. 40, No. 4-5, 1999, pp. 21-28. doi:10.1016/S0273-1223(99)00481-3

[15] P. Gikas and G. Tchobanoglous, “The Role of Satellite and Decentralized Strategies in Water Resources Management," Journal of Environmental Management, Vol. 90, No. 1, 2009, pp. 144-152. doi:10.1016/j.jenvman.2007.08.016

[16] N. Kantanoleon, L. Zampetakis and T. Manios, "Public Perspective towards Wastewater Reuse in a Medium Size, Seaside, Mediterranean City: A Pilot Survey,” Resources, Conservation and Recycling, Vol. 50, No. 3, 2007, pp. 282-292. doi:10.1016/j.resconrec.2006.06.006

[17] A. N. Angelakis and B. Durham, "Water Recycling and Reuse in EUREAU Countries: Trends and Challenges," Desalination, Vol. 218, No. 1-3, 2008, pp. 3-12. doi:10.1016/j.desal.2006.07.015

[18] A. B. Pittock, "Climate Change: An Australian Guide to the Science and Potential Impacts," Australian Greenhouse Office, Canberra, 2003.

[19] J. W. Hopmans, E. P. Maurer and G. Schoups, "Impact of Climate Change on Crop Water Requirements, Groundwater and Soil Salinity in the San Joaquin Valley," California Central Valley Groundwater Modeling Workshop, Berkeley, 10-11 July 2008.

[20] M. Polemio, V. Dragone and P. Limoni, "Monitoring and Methods to Analyse the Groundwater Quality Degradation Risk in Coastal Karstic Aquifers (Apulia, Southern Italy)," Environmental Geology, Vol. 58, No. 2, 2009, pp. 299-312. doi:10.1007/s00254-008-1582-8

[21] A. Hameed, M. J. Alobaidy, M. A. Al-Sameraiy, A. J. Kadhem and A. A. Majeed, "Evaluation of Treated Municipal Wastewater Quality for Irrigation," Journal of Environmental Protection, Vol. 1, No. 3, 2010, pp. 216225. doi:10.4236/jep.2010.13026

[22] A. A. Murad, “An Overview of Conventional and Non-Conventional Water Resources in Arid Region: Assessment and Constrains of the United Arab Emirates (UAE)," Journal of Water Resource and Protection, Vol. 2, 2010, pp. 181-190.

[23] FAO, "Climate Change Adaptation and Mitigation: Challenges and Opportunities for Food Security Rome," High-Level Conference on World Food Security: The Challenges of Climate Change and Bioenergy, 3-5 June 2008.

[24] J. Andréasson, S. Bergström, B. Carlsson, L. P. Graham and G. Lindström, "Hydrological Change: Climate Impact Simulations for Sweden,” Ambio, Vol. 33, No. 4-5, 2004, pp. 228-234. 
[25] IPCC Intergovernmental Panel on Climate Change, "Climate Change and Water Technical Paper VI,” June 2008.

[26] H. Chang, C. G. Knight, M. P. Staneva and D. Kostov, "Water Resource Impacts of Climate Change in Southwestern Bulgaria," GeoJournal, Vol. 57, No. 3, 2002, pp. 159-168. doi:10.1023/B:GEJO.0000003611.11187.5c

[27] P. Etchevers, C. Golaz, F. Habets and J. Noilhan, "Impact of a Climate Change on the Rhone River Catchment Hydrology,” Journal of Geophysical Research, Vol. 107, No. D16, 2002, p. 4293. 10.1029/2001JD000490

[28] L. Menzel and G. Bürger, "Climate Change Scenarios and Runoff Response in the Mulde Catchment (Southern Elbe, Germany)," Journal of Hydrology, Vol. 267, No.
1-2, 2002, pp. 53-64. doi:10.1016/S0022-1694(02)00139-7

[29] A. Iglesias, T. Estrela and F. Gallart, "Impactos Sobre los Recursos Hídricos,” In: J. M. Moreno, Ed., Evaluación Preliminar de los Impactos en España for Efecto del Cambio Climático, Ministerio de Medio Ambiente, Madrid, 2005, pp. 303-353.

[30] Interenvironment Institute, "The Malibu Declaration: Cities and Conservation in Mediterranean-Type Ecosystems," Proceedings of Workshop: Design an Intercontinental Program on Cities and Conservation in Mediterranean-Type Ecosystems, Malibu, 21-24 March 2004. 